\title{
How Can Terrorism Be Prevented?: Special Reference to "Kotiyagala Village" in Monaragala District of Sri -Lanka from 1995 - 2009
}

\section{H. Ranjith ${ }^{1^{*}}$, Ravindra Chandrasiri Palliyaguruge ${ }^{1}$}

${ }^{1}$ Department of the Social Sciences, Faculty of Social Sciences and Languages, Sabaragamuwa University of Sri Lanka, Belihuloya. *ranjith@sab.ac.lk

\begin{abstract}
Abstact
This paper is going to examine what the effective method of terrorism prevention. Identification of terrorism and role of the civil society in the counter terrorist measures were the objectives of this research. The research was based on primary data gathered from 150 interviewees using structured questionnaires. Random Sampling Method was used to collect primary data. In addition to using a structured questionnaire, the officers such as Army, Police, teachers, lecturers, farmers were interviewed. Except lecturers, the other interviewees were selected from "kotiyagala village" at "siyabalanduwa" additional secretariat in Monaragala District. Kotiyagala is a village which has been victimized since 1983 by the LTTE. Our research was referenced the "KOTIYAGALA VILLAGE" in the Monaragala district in Sri - Lanka. It is not a land which had to born terrorism or so called "Border Village". But intimidation of terrorism had been on there. The villagers have been victimized three times since 1995. Even thou terrorist suppression methods that have been succeed in other areas; they could not suitable for KOTIYAGALA. The villages insisted on the necessary of armed weapons to face terrorist, armed training for both male and female. They said that if they could organize as small groups with arms, they can guard their village. In this sense they implied that the necessity of volunteer armed groups for each village. The research explore that even thou terrorism had been defeated it would not be able to prevent without the active participate of civil societies. Terrorism emerges on the base of factors that had been created by the society through its injustice societal activities. According to the study, root causes which will be led to the emergence of terrorism want to be eradicated to prevent terrorism. There is an active participation of civil society, the terrorism prevention would be fruitful.
\end{abstract}

Key words: Terrorism, civil society, Sri Lanka

\section{Introduction}

Terrorism has currently been emerged a perilous disaster against to the humanity. Even thou Terrorism have been identified as modern 
phenomenon, it has very long history (Martin, 2006), (Chaliand, and Arnaud: 2007). Lots of counter measures on Terrorism had been implemented by national and regional level. It was difficult to define and take successful counter terrorist attacks on the ground of Cold War world context. However, bi-polar world system was disappeared after the collapse of USSR led Soviet bloc in 1989. After the incident of September 11, President Jorge W. Bush proclaimed 'War on Terror' as an inevitable part of USA foreign policy (Dobrot, 2007). After that, Terrorism has taken into notice to the wider community as a Global Phenomenon. In this pragmatic world context, obliteration of the terrorism is necessary task on behalf of the humanity and peaceful coexistence.

\section{Research problem and objectives}

The research problem of this study is to question terrorism preventive methods. Terrorism is being depowered by using two major strategies. One of them is called "Terrorism preventing" and other one is named "Terrorism Oppression". The paper will seek what is the most prominent and efficient method of depriving terrorism.

1. Identify definitions on terrorism,

2. Identify what the effective method of terrorism prevention,

3. To identify the role of the civil societies in the terrorism preventing process.

\section{Hypothesis}

Hypothesis of the study was that there was no active participation of civil societies the terrorism would not be prevented.

\section{Methodology}

The purpose of this study is to explore, as well as understand, how to prevent terrorism perfectly. Qualitative approach was found to be most suitable for this type of research. Qualitative research is a systematic, empirical strategy for answering questions about people in abounded social context. Moreover, it is a means for describing and attempting to understand the observed regularities in what people do, say, and report as their experience (Looke 1993). In this approach, the researchers deal with the words of the participants by which they describe their feelings and explanations of events. Researchers treat these feelings and explanations as significant realities. For this reasons, a qualitative approach suits this kind of inquiry more than a quantitative one. 
The research was based on primary data gathered from 150 interviewees using structured questionnaires. Random Sampling Method was used to collect primary data. In addition using a structured questionnaire, the officers such as Army, Police, teachers, lecturers, farmers were interviewed. Except lecturers, the other interviewees were selected from "kotiyagala village" at "siyabalanduwa" additional secretariat in Monaragala District. Kotiyagala is a village which has been victimized since 1983 by the LTTE. The Minitab statistical computer package was used to analyze data. Secondary data were also used to construct theoretical background.

\section{Literature review}

Terrorism is defined as an organized system of intimidation (Goyal 1990). Chalmers Johnson, in his article on 'Perspective of Terrorism' defines terrorism as " terrorism involves the intentional use of violence or threat of violence by the precipitator against an instrumental target in order to communicate to a primary target a threat of future violence" (Johnson 1974). Lawrence Zelic Freedman interpreted terrorism as the following " terrorism is defined as the use of violence when its most important result is not the physical and mental damage of the direct victims but the psychological effect produced on someones" (Freedman 1985). A, Schmid could be able to create consensus definition of terrorism in "Political Terrorism: A Research Guide to Concept, Theories, Data bases, and Literature". It is consisted in five parts. First, terrorism is a method of combat in which random or symbolic victims are targets of violence. Second, through previous use of violence or the credible threat of violence, other members of that group or class are put in a state of chronic fear. Third, the victimization of the target is considered beyond the norms of civilized society. Fourth, this victimization creates an audience beyond the target of terror. Fifth, the purpose of terrorism is either to immobilize the target of terror in order to produce disorientation or compliance. However, he has neglected terrorist acts that had been done by against the property. According to the J, Gibbs terrorism can be defined as any illegal violence or threat of violence directed against human or nonhuman objects (Gibbs 1989). For the Central Intelligence Agency and U.S. State Department of Title 22 of the U.S. Code - Section $2656 \mathrm{f}$ (d) "The term 'terrorism' means premeditated, politically motivated violence perpetrated against noncombatant targets by sub national groups or clandestine agents, usually intended to influence an audience. The term 'international terrorism' means terrorism involving the territory or the citizens of more than one country. The terms of 'terrorist group' can be identified as any group that practices, or has significant subgroups that practice, international terrorism" (Burns and Peterson 2005).

The Federal Bureau of Investigation (FBI) promulgates the terrorism as "The unlawful use of force or violence against persons or property to intimidate 
or coerce a Government, the civilian population, or any segment thereof, in furtherance of political or social objectives (Burns and Peterson 2005).

The FBI further describes terrorism as either domestic or international, depending on the origin, base, and objectives of the terrorist organization.

Domestic terrorism involves groups or individuals who are based and operate entirely within the United States and Puerto Rico without foreign direction and whose acts are directed at elements of the U.S. Government or population.

International terrorism is the unlawful use of force or violence committed by a group or individual, who has some connection to a foreign power or whose activities transcend national boundaries, against person or property to intimidate or coerce a government, the civilian population, or any segment thereof, in furtherance of political or social objectives. According to the United Kingdom Terrorist Act 2000;

“(1) in this Act 'terrorism' means the use or threat of action where-

(a) The action falls within subsection (2),

(b) The use or threat is designed to influence the government or to intimidate the public or a section of the public, and

(c) The use or threat is made for advancing a political, religious or ideological cause.

(2) Action falls within this subsection if it-

(a) involves serious violence against a person,

(b) involves serious damage to property,

(c) endangers a person's life, other than that of the person committing the action,

(d) Creates a serious risk to the health or safety of the public or a section of the public,

or

(e) is designed seriously to interfere with or seriously to disrupt an electronic system.

(3) The use of threat of action falling within subsection (2) which involves the use of firearms or explosives is terrorism whether or not subsection (1)(b) is satisfied (Burns and Peterson 2005:9).

The Council of the European Union enacted the terrorist offences act. Article number 3 of that states "Each Member State shall take the necessary measures to ensure that the following offences, defined according to its national law, 
which are intentionally committed by an individual or a group against one or more countries, their institutions or people with the aim of intimidating them and seriously altering or destroying the political, economic, or social structures of a country, will be punishable as terrorist offences:

(a)Murder; (b) Bodily injuries; (c) Kidnapping or hostage taking; (d) Extortion; (e) Theft or robbery; (f) Unlawful seizure of or damage to state or government facilities, means of public transport, infrastructure facilities, places of public use, and property; (g) Fabrication, possession, acquisition, transport or supply of weapons or explosives; (h) Releasing contaminating substances, or causing fires, explosions or flood, endangering people, property, animals or the environment; (i) Interfering with or disrupting the supply of water, power, or other fundamental resource; (j) Attacks through interference with an information system; (k) Threatening to commit any of the offences listed above; (1) Directing a terrorist group; (m) Promoting of; Supporting of or participating in a terrorist group(Burns and Peterson 2005).

This brief overview of the problem of defining terrorism provides a legitimate ground for the first research objective of this study that is being defined terrorism with a common sense. However, there is no internationally accepted perfectible definition on terrorism. On the other hand, it is a major obstacle faced in the terrorism preventing efforts in the modern world. Even thou, few basic characteristics of terrorism can be identified as follows:

1. There is an intentional act or series of them.

2. Terrorism can be seen as an isolated action or chain of such incidents.

3. The groups of people may do it.

4. Terrorist activities are highly organized.

5. Brutal violence can see in the terrorism.

6. Terrorist activities target the armed process of government.

7. It usually targets the Civilians, Political, Economical and materialistic structures.

8. Very often terrorism may be used as a method that had to be used for communication.

9. Ideological, Religious or Economical aims are behind the terrorism.

10.The terrorist may use every efforts and strategies that have never been used or heard by the human. 


\section{Findings}

Lots of strategies to prevent terrorism have been used by sophisticated world. Most popular one of them is oppression. Very often domestic terrorists are organized as the small guerilla groups. So it is very hardened to suppress them by conventional armed forces, even thou they have sophisticated weapons and war capability. That is a reason why the U.S.A. could not be able to prevent terrorist activities in IRAQUE and AFGANISTHAN, which was revealed by the research.

\section{Success of the armed Forces}

On the other hand, both conventional and guerilla strategies of war against the LTTE were used by Sri Lankan armed forces. As the result of that Sri Lankan armed forces achieved giant victory.

\section{Nature of "KOTIYAGALA VILLAGE"}

Our research was referenced the "KOTIYAGALA VILLAGE" in the Monaragala district in Sri - Lanka. It is not a land which had to born terrorism or so called "Border Village". But intimidation of terrorism had been on there. The villagers have been victimized three times since 1995. Even thou terrorist suppression methods that have been succeed in other areas; they could not suitable for KOTIYAGALA.

\section{Feelings of villages}

In this circumstance, villagers were being empowered against to the terrorist. They want to secure their families, harvests and land. They do not have any idea to abandon their lands which were received by the ancestors. The villages treated them as their family heritage. The villages insisted on the necessary of armed weapons to face terrorist, armed training for both male and female. They said that if they could organize as small groups with arms, they can guard their village. In this sense they implied that the necessity of volunteer armed groups for each village.

\section{International Experience}

Such a method had been practiced in the USSR to face the "White Terror" Which had been culminated after the Bolshevik Revolution. This research revealed that if it selects the suppressive methods to prevent terrorism it would not be succeed without the conscious and active participation of ordinary people, sometimes they want to be empowered with armed weapons. 


\section{Prevention of Terrorism}

The research explore that even thou terrorism had been defeated it would not be able to prevent without the active participate of civil societies. Terrorism has been emerged on the base of factors that had been created by the society through its injustice societal activities. According to the study, root causes which will be led to the emergence of terrorism want to be eradicated to prevent terrorism.

\section{Conclusions and Suggestions}

Hypothesis of the study was that there was no active participation of civil societies the terrorism would not be prevented. Finally it was proved. The terrorism can be prevented successfully with the involvement of civil society rather than by using the suppressive methods. According to the research, prevention of terrorism would be achieved through the equal opportunity for all in the society and capabilities of them for the society. Therefore, the research suggests that such a circumstance should be established in a political, Economical and Social structures.

\section{References}

Burns, V and Peterson, D. k. (2005). TERRORISM: A Documentary and Reference Guide, Greenwood Press, London.

Chaliand, Gérard., and Arnaud, B. (2007) 'THE PREHISTORY OF TERRORISM: Zealots and Assassins' in THE HISTORY OF TERRORISM FROM ANTIQUITY TO AL QAEDA, Gérard Chaliand and Arnaud Blin(ed.), Los Angeles: University of Califoniya Press.

Dobrot (2007) THE GLOBAL WAR ON TERRORISM: A RELIGIOUS WAR?, USA: The Strategic Studies Institute. (Available at http://www. strategicstudiesinstitute.army.mil/pdffiles/pub822.pdf)

Freedman, L.Z. (1985).Terrorism: Problems of the Polister axic, an article in "Perspective in Terrorism", Lawrence Zelic Freedman and Yonah Alexander ed, Hindustan Publishing Corporation, New Delhi.

Goyal, A. (1990). TERRORISM: causes and consequences, Institute of Environment, Bikaner.

Gibbs, J. (1989). Conceptualization of Terrorism, American Sociological Review,54,329-340.

Johnson, C. (1974). Perspective of Terrorism, an article in the "Terrorism Reader: A Historical Anthology", Water Laquer ed, Wildwood House, London. 
Looke, 1., S, W. and Silverman, S. (1993). Proposals that work: A Guide for Planning Dissertations and Grant Proposals, Newbury Park, CA, Sage.

Martin, Gus (2006) Understanding Terrorism: Challenges, Perspectives and Issues, London: Sage Publication 